\title{
STUDI FAKTOR PENENTU PENERIMAAN DAN PENGGUNAAN SISTEM INFORMASI AKUNTANSI PADA LEMBAGA PERKREDITAN DESA
}

\author{
I Made Suarta dan IGA Oka Sudiadnyani
}

\author{
Jurusan Akuntansi, Politeknik Negeri Bali \\ Jln. Kampus Bukit Jimbaran, Badung, Bali. 80364 \\ Email: i_md_suarta@yahoo.co.id
}

\begin{abstract}
This study examines the acceptance of computer-based accounting information systems at the Village Micro Financial Institutions (Lembaga Perkreditan Desa or LPD), by adopting the Technology Acceptance Model (TAM). Modification of the model performed on external factors, because these factors are determined by the LPD's background as a traditional financial institution owned by indigenous villages. The study uses a non-experimental quantitative approach and ex-post facto research. Data collected by survey method, using a questionnaire. The respondents were selected randomly proportional from employees LPD in Badung regency and Denpasar city. The operational transaction processing, financial and management reporting at LPD is not fully utilizing computerbased accounting information system. Meanwhile, the structural model developed based on the theoretical study is not well supported by empirical data. The total effect of external factors on the actual use of computer-based accounting information systems in the LPD is not significant. Further research is needed, with revise the model and consider additional indicators as part of the external variables in order to provide a comprehensive model.
\end{abstract}

Keywords: accounting information systems, information technology, technology acceptance model, village micro financial institutions (LPD), structural equation model.

\begin{abstract}
Abstrak
Penelitian ini mengkaji penerimaan sistem informasi akuntansi berbasis komputer pada LPD di Bali, mengadopsi Technology Acceptance Model (TAM). Modifikasi dilakukan pada faktor eksternal, karena faktor ini sangat ditentukan oleh latar belakang LPD sebagai lembaga keuangan milik desa adat yang bersifat tradisional. Penelitian menggunakan pendekatan kuantitatif non-eksperimen dan bersifat $e x-$ post facto. Pengumpulan data dilakukan dengan metode survei, menggunakan kuesioner sebagai alat pengumpul data. Sampel penelitian diambil secara acak proporsional (proportional random sampling) dari karyawan LPD yang ada di Kabupaten Badung dan Kota Denpasar. Operasional LPD dalam pemrosesan transaksi, pelaporan keuangan dan pelaporan manajemen belum sepenuhnya memanfaatkan sistem informasi akuntansi berbasis komputer. Sementara itu, model hubungan struktural yang dikembangkan berdasarkan kajian teoritis belum sepenuhnya didukung oleh data empiris. Pengeruh faktor eksternal terhadap penggunaan sesungguhnya sistem informasi akuntansi berbasis komputer di lingkungan LPD bersifat tidak nyata. Perlu dilakukan kajian lanjutan dengan merevisi model serta mempertimbangkan indikator-indikator tambahan sebagai bagian dari variabel eksternal agar dapat memberikan gambaran yang lebih komprehensif.
\end{abstract}

Kata Kunci: sistem informasi akuntansi, teknologi informasi, technology acceptance model, lembaga perkreditan desa, model persamaan struktural.

\section{Pendahuluan}

Saat ini, teknologi infomasi sudah menjadi kebutuhan dasar bagi setiap perusahaan dalam menjalankan aktifitas bisnisnya. Kombinasi sistem informasi akuntansi (SIA) dengan teknologi informasi telah menjelma menjadi alat bantu utama dalam pengelolaan dan pengendalian terkait keuangan perusahaan. Kemajuan teknologi informasi telah membuka peluang untuk menghasilkan dan memanfaat- kan informasi akuntansi dari sudut pandang strategis [1].

Penggunaan sistem informasi akuntansi berbasis komputer telah membawa peluang bagi perusahaan untuk melakukan fungsi akuntansi secara lebih efektif dan efisien. Dampak terbesar dari penerapan teknologi informasi pada SIA adalah kemampuan perusahaan untuk mengembangkan dan menggunakan sistem komputerisasi dalam melacak dan merekam transaksi keuangan. Ghasemi et 
al. menyebutkan manfaat dari sistem informasi akuntansi yang terkomputerisasi di antaranya: meningkatkan ketepatan waktu dalam penyajian informasi akuntansi, meningkatkan akurasi pencatatan transaksi, pengolahan data dan penyajian informasi menjadi lebih cepat, serta pelaporan bagi pihak eksternal menjadi lebih baik dan kredibel [2].

Keberhasilan penerapan teknologi informasi di samping ditentukan aspek perangkat keras dan perangkat lunak, juga ditentukan oleh pengguna teknologi tersebut. Hasil-hasil penelitian menunjukkan kegagalan penerapan teknologi informasi lebih disebabkan oleh faktor perilaku penggunanya [3], [4]. Terlebih, pada lembaga usaha di mana sumber daya manusianya tidak secara khusus dipersiapkan untuk menggunakan teknologi informasi. Aspek keprilakuan dalam konteks manusia sebagai pengguna teknologi informasi menjadi penting diperhatikan dalam penerapan teknologi informasi [5].

Sejak tahun 1984, di Bali mulai dikembangkan lembaga keuangan mikro yang dinamakan Lembaga Perkreditan Desa (LPD). Data per Agustus 2013 menunjukan jumlah LPD di Bali mencapai 1.421 dari jumlah desa yang ada yakni 1.480. Total aset yang dikelola mencapai $\mathrm{Rp} 9,8$ triliun lebih (postbali.com, 25 November 2013). Meningkatnya jumlah aset yang dikelola oleh setiap LPD, diikuti dengan meningkatnya volume transaksi keuangan. Dukungan teknologi informasi dalam operasional usaha LPD menjadi hal yang sangat penting. Pengamatan empirik di lapangan menunjukkan, penggunaan teknologi informasi pada LPD masih sangat rendah. Kondisi ini tidak terlepas dari LPD sebagai lembaga keuangan yang berangkat dari organisasi tradisional, dikelola oleh sumber daya manusia dengan tingkat pengetahuan dalam bidang teknologi informasi yang terbatas.

Supaya teknologi informasi dapat diterima dengan baik di lingkungan LPD, maka perilaku pengguna perlu diubah. Merubah perilaku pengguna tidak dapat dilakukan secara langsung, tetapi dilakukan lewat penentu-penentu perilaku tersebut. Kajian aspek keperilakuan dalam penerimaan dan penggunaan teknologi informasi pada dunia usaha telah berkembang seiring dengan meningkatnya kecenderungan dunia usaha memanfaatkan teknologi informasi dalam mendukung aktifitas bisnisnya. Berbagai model telah dikembangkan untuk mengkaji penentu-penentu perilaku yang mempengaruhi penerimaan atau penggunaan teknologi informasi, seperti Theory of Reasoned Action (TRA), Theory of Planned Behavior (TPB), serta Technology Acceptance Model (TAM).

Technology Acceptance Model (TAM) merupakan salah satu model yang banyak digunakan dalam penelitian untuk mengkaji perilaku penerimaan teknologi informasi. TAM yang dikembang- kan oleh Davis mengadopsi Theory of Reasoned Action (TRA). Persepsi kemudahan menggunakan (perceived ease of use) dan persepsi kebermanfaatan (perceived usefulness) merupakan dua indikator kunci yang menentukan penerimaan individual terhadap teknologi informasi. Pembentukan persepsi kebermanfaatan dan kemudahan menggunakan, menentukan sikap terhadap penggunaan (attitude towards using technology), pada gilirannya membentuk minat perilaku menggunakan teknologi informasi (behavioral intention to use) dan akhirnya mempengaruhi penggunaan teknologi informasi (actual technology use) [5].

Model TAM yang dikembangkan oleh Davis telah banyak dikaji ulang, direplikasi dan dikembangkan oleh peneliti-peneliti lainnya [6], [7], [8], [9], [10]. Penelitian aspek keperilakuan dalam pemanfaatan teknologi informasi terus berkembang seperti yang dilakukan oleh Adamson \& Shine [11], Barnett et al. [12], Fagan et al. [13], Jones et al. [14], dan Ilias \& Nazirah [4]. Hasil-hasil penelitian tersebut menunjukkan model TAM secara konsisten dan valid dapat menjelaskan tentang perilaku penerimaan teknologi informasi.

Beberapa peneliti juga mengembangkan model TAM dengan menambahkan beberapa variabel eksternal yang menjadi penentu dari persepsi kebermanfaatan dan kemudahan menggunakan. Variabel-variabel eksternal yang digunakan seperti variabel-variabel individual, organisasi, kultur, dan karakteristik tugas [15], [16], [17], [18], [19], [20].

Penelitian ini mengkaji faktor penentu penerimaan dan penggunan sistem informasi akuntansi berbasis komputer pada LPD di Bali, mengadopsi Technology Acceptance Model yang dikembangkan oleh Davis [5]. Konstruk utama dalam penelitian sebelumnya yang meliputi persepsi kebermanfaatan, persepsi kemudahan menggunakan, dan sikap terhadap penggunaan teknologi informasi tetap dipertahankan. Modifikasi dilakukan pada faktor eksternal, mengingat faktor ini dipengaruhi oleh latar belakang LPD sebagai lembaga keuangan yang berangkat dari lembaga adat dan bersifat tradisional. Berkenaan dengan hal tersebut permasalahan utama yang ingin diungkap adalah apakah faktorfaktor eksternal berpengaruh terhadap persepsi kebermanfaatan dan kemudahan menggunakan sistem informasi akuntansi, serta bagaimana implikasinya terhadap penggunaan sesungguhnya sistem informasi akuntansi.

\section{Metodologi}

Penelitian ini menggunakan pendekatan kuantitatif non-eksperimen dan bersifat ex-post facto. Pengumpulan data dilakukan dengan metode survei, menggunakan kuesioner sebagai alat pengumpul data. Sampel penelitian diambil secara acak pro- 


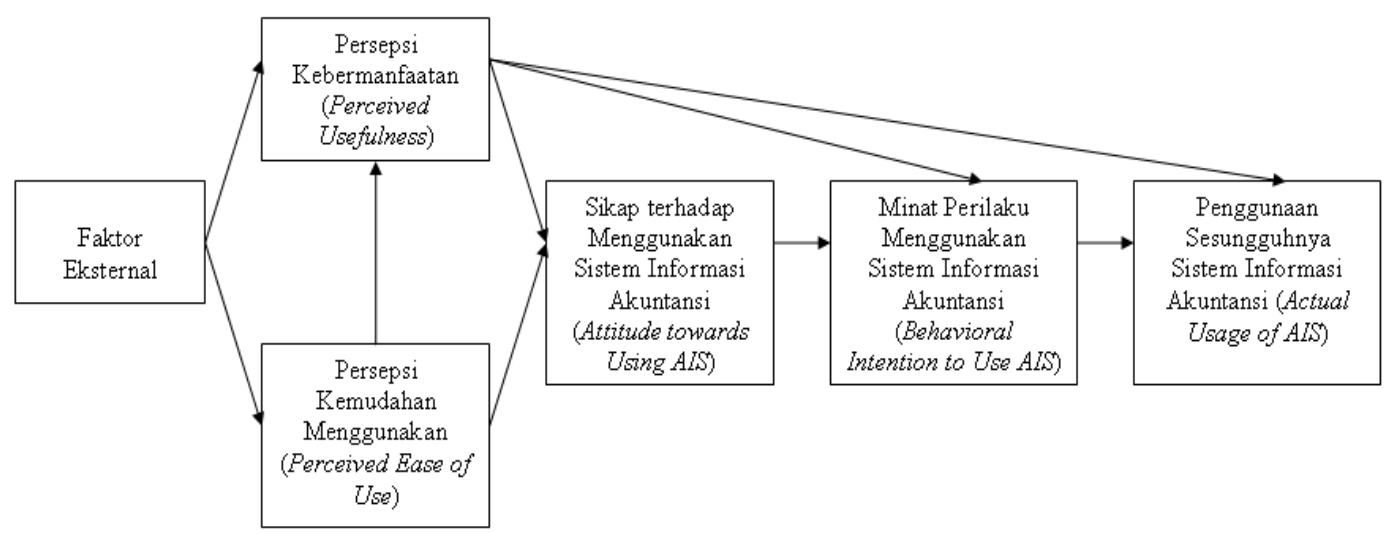

Gambar 1. Kerangka konseptual penelitian

porsional dari karyawan LPD di Kabupaten Badung dan Kota Denpasar.

Model penelitian dikembangkan menggunakan persamaan struktural (structural equation model) yang menggambarkan hubungan-hubungan linear di antara variabel-variabel laten. Variabel laten merupakan konsep abstrak, hanya dapat diamati secara tidak langsung melalui efeknya pada variabel teramati. Model hubungan di antara variabel-variabel laten seperti pada Gambar 1. Kuesioner penelitian disusun dalam bentuk pernyataan tertutup menggunakan skala Likert lima tingkat. Keseluruhan instrumen penelitian terdiri atas 25 butir pertanyaan. Butir-butir pertanyaan variabel persepsi kebermanfaatan (perceived usefulness), persepsi kemudahan menggunakan (perceived ease of use), sikap menggunakan sistem informasi akuntansi (attitude toward using), minat menggunakan sistem informasi akuntansi (intention to use), dikembangkan dan diadaptasi dari Davis [5] (Tabel $1)$.

TABEL 1

BUTIR-BUtIR PERTANAAN YANG DiKEMBANGKAN

\begin{tabular}{ll}
\hline Persepsi kebermanfaatan sistem informasi akuntansi (perceived usefulness) \\
\hline 1. & Sistem informasi akuntansi menjadikan pekerjaan terasa lebih mudah \\
2. & Sistem informasi akuntansi meningkatkan kualitas pekerjaan \\
3. & Sistem informasi akuntansi meningkatkan produktivitas pekerjaan \\
4. & Dengan sistem informasi akuntansi, penyelesaian pekerjaan menjadi lebih cepat \\
5. & Secara kesluruhan, sistem informasi akuntansi mampu meningkatkan kinerja \\
\hline Persepsi kemudahan menggunakan sistem informasi akuntansi (perceived ease of use) \\
\hline 1. & Mempelajari penggunaan sistem informasi akuntansi sangat mudah \\
2. & Interaksi pemakai dengan sistem informasi akuntansi sangat jelas \\
3. & Instruksi-instruksi dalam sistem informasi akuntansi mudah dipahami \\
4. & Secara keseluruhan, sistem informasi akuntansi sangat mudah dioperasikan \\
\hline Sikap menggunakan sistem informasi akuntansi (attitude toward using) \\
\hline 1. & Menggunakan sistem informasi akuntansi merupakan gagasan yang sangat baik \\
2. & Menggunakan sistem informasi akuntansi membuat pekerjaan lebih menarik \\
3. & Bekerja dengan sistem informasi akuntansi menyenangkan \\
4. & Sistem informasi akuntansi memotivasi saya untuk bekerja lebih baik \\
5. & Saya suka bekerja dengan sistem informasi akuntansi \\
\hline Minat menggunakan sistem informasi akuntansi (Intention to Use) \\
\hline 1. & Saya tertarik untuk mempelajari penggunaan sistem informasi akuntansi \\
2. & Saya berniat menggunakan sistem informasi akuntansi dalam bidang pekerjaan saya \\
3. & Saya berniat menggunakan sistem informasi akuntansi dalam pembuatan laporan keuangan \\
4. & Saya berniat mengusulkan penggunaan sistem informasi akuntansi dalam operasional LPD \\
\hline
\end{tabular}


Butir-butir pertanyaan berkaitan dengan penggunaan sesungguhnya sistem informasi akuntansi dikembangkan dari indikator-indikator penggunaan SIA (Tabel 2). Sementara butir-butir pertanyaan variabel eksternal dikembangkan dengan memperhatikan karakteristik LPD yang berbasis pada masyarakat adat dan bersifat tradisional. Faktor eksternal yang diidentifikasi meliputi: (1) latar belakang LPD sebagai lembaga adat dan bersifat tradisional, serta (2) kultur sumber daya manusia pengelola LPD.

Uji validitas instrumen penelitian dilakukan menggunakan korelasi Pearson Product Moment dengan $\alpha=5 \%$. Hasil uji menunjukkan validitas yang signifikan dengan koefisien product moment bervariasi antara $0.516-0.845$. Sedangkan uji reliabilitas dilakukan dengan menggunakan Cronbach's Alpha. Hasil uji raliabilitas menunjukkan nilai Cronbach's Alpha bervariasi antara 0.509 0.816 .

Hasil penelitian dianalisis menggunakan model persamaan struktural dengan bantuan program LISREL 8.51 for Windows. Analisis model persamaan struktural dimaksudkan untuk menganalisis serangkaian hubungan di antara variabel-variabel penelitian secara simultan. Kesesuaian model struktural dievaluasi menggunakan beberapa fit index (indeks kesesuaian), seperti: Chi-Square Statistic $\left(\Pi^{2}\right)$, Goodness of Fit Index (GFI), Adjusted Goodness of Fit Index (AGFI), Non-normed Fit Index (NNFI), Comparative Fit Index (CFI), Root Mean Square Residual (RMSR), dan the Root Mean Square Error of Approximation (RMSEA).

\section{Hasil dan Pembahasan}

\section{Penggunaan Sistem Informasi Akuntansi di Lingkungan LPD}

Sistem informasi akuntansi yang dimaksudkan dalam penelitian ini adalah sistem yang berbasis pada teknologi informasi. Konstruk perilaku (behavior) dalam TAM merupakan tindakan yang dilakukan oleh seseorang. Dengan kata lain, perilaku (behavior) merupakan penggunaan sesungguhnya (actual usage) dari sistem informasi tersebut. Penggunaan sesungguhnya dari sistem informasi akuntansi di lingkungan LPD diukur menggunakan indikatorindikator: (1) waktu yang digunakan untuk berinteraksi dengan sistem informasi akuntansi, (2) frekuensi penggunaannya, dan (3) keterampilan dalam menggunakan sistem informasi. Deskripsi penggunaan sesungguhnya sistem informasi akuntansi di lingkungan LPD disajikan pada Tabel 2.

Terdapat 122 responden $(54.2 \%)$ yang menggunakan waktu kerjanya dalam sehari untuk berinteraksi dengan sistem informasi akuntansi lebih dari 4 jam. Sebanyak 59 responden $(26.2 \%)$ yang fre- kuensi penggunaan sistem informasi akuntansi dalam kategori sering dan sangat sering. Sebaliknya, terdapat 166 responden $(73.8 \%)$ responden yang frekuensi penggunaannya dalam kategori tidak pernah hingga jarang. Sementara itu, keterampilan karyawan LPD dalam menggunakan sistem informasi akuntansi sudah cukup baik. Sebanyak 140 responden $(62.3 \%)$ mempunyai keterampilan dalam kategori terampil dan sangat terampil. Hanya $18.3 \%$ yang menyatakan dirinya tidak atau kurang terampil.

TABEL 2

PENGGUNAAN SESUNGGUHNYA SiSTEM INFORMASI AKuntansi $(N=225)$

\begin{tabular}{llcc}
\hline \multicolumn{1}{c}{ Indikator Penggunaan SIA } & Frekuensi & $\%$ \\
\hline $\begin{array}{l}\text { Waktu yang } \\
\text { digunakan untuk }\end{array}$ & <1 jam & 6 & 2.7 \\
$\begin{array}{l}\text { berinteraksi } \\
\text { dengan sistem }\end{array}$ & $1-2$ jam & 30 & 13.3 \\
$\begin{array}{l}\text { informasi } \\
\text { akuntansi } \\
\text { (jam/hari kerja) }\end{array}$ & $4-5$ jam jam & 67 & 29.8 \\
\hline $\begin{array}{l}\text { Frekuensi } \\
\text { penggunaan } \\
\text { sistem informasi } \\
\text { akuntansi }\end{array}$ & Tidak pernah & 103 & 45.8 \\
& Sangat jarang & 19 & 8.4 \\
\hline $\begin{array}{l}\text { Keterampilan } \\
\text { dalam } \\
\text { menggunakan } \\
\text { sistem informasi } \\
\text { akuntansi }\end{array}$ & Sering & 129 & 6.7 \\
& Kurang & 50 & 22.2 \\
& Sukup terampil & 44 & 12.9 \\
& Terampil & 116 & 51.6 \\
\hline & Sangat terampil & 24 & 10.7 \\
\hline
\end{tabular}

Penelitian ini mengindikasikan penggunaan sesungguhnya sistem informasi akuntansi di LPD masih rendah. Hal ini ditandai oleh masih banyaknya responden $(45.8 \%)$ menggunakan kurang dari setengah waktu kerjanya dalam sehari berinteraksi dengan sistem informasi akuntansi. Karyawan yang waktu kerjanya banyak digunakan untuk berinteraksi dengan sistem informasi akuntansi adalah karyawan bagian front-line seperti teller, dan karyawan bagian back-office seperti bagian keuangan dan akuntansi. Secara kuantitatif, jumlah karyawan LPD pada posisi ini pada umumnya tidak banyak.

Frekuensi penggunaan sistem informasi akuntansi termasuk dalam kategori sangat rendah. Hasil ini sejalan dengan waktu yang digunakan berinteraksi dengan sistem informasi akuntansi, di mana cukup banyak karyawan yang berinteraksi dengan sistem informasi akuntansi kurang dari 4 jam sehari. Temuan ini juga didukung oleh tingkat keterampilan karyawan LPD, di mana hampir $40 \%$ karyawan LPD dalam kategori tidak terampil hingga cukup terampil. Upaya penggunaan sistem informasi 


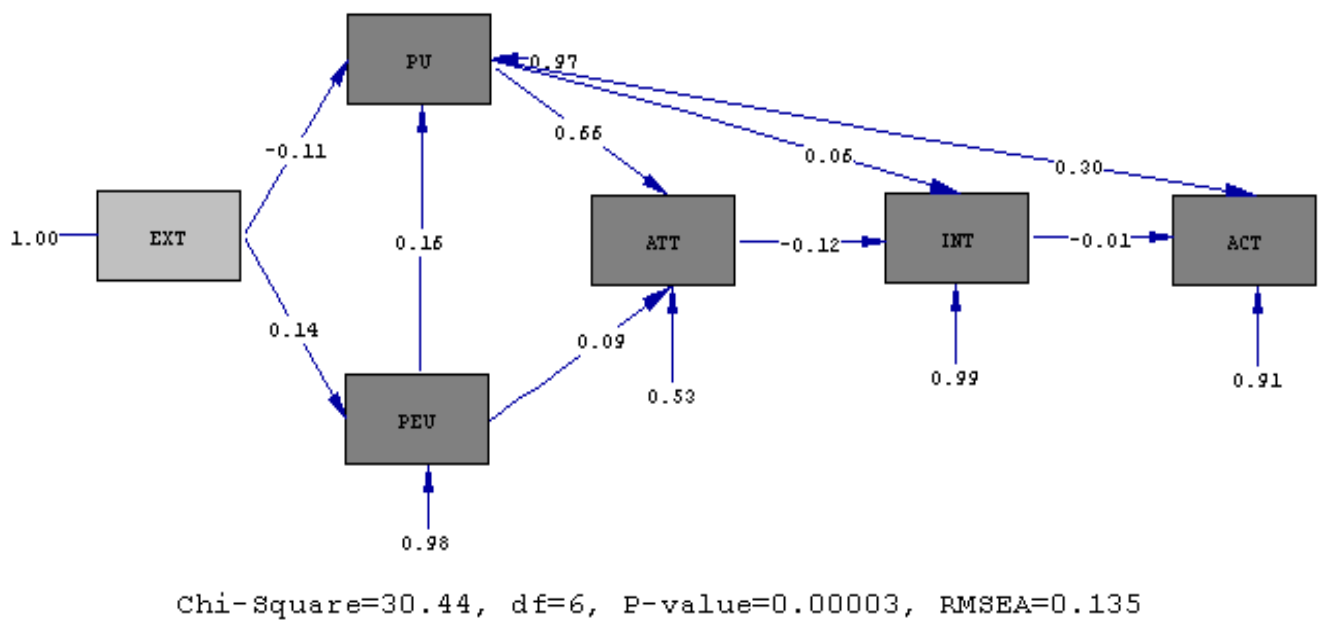

Gambar 2. Model lintasan dengan estimasi standardized solution

akuntansi di lingkungan LPD secara maksimal, perlu didukung oleh berubahnya perilaku karyawan dalam memanfaatkan sistem informasi baru. Perubahan perilaku karyawan ditandai oleh kemauan untuk selalu belajar dan meningkatkan keterampilan dalam menggunakan sistem informasi akuntansi berbasis komputer.

\section{Analisis Model Persamaan Struktural}

Model persamaan struktural menggambarkan hubungan-hubungan linear di antara variabel-variabel laten. Sebuah hubungan di antara variabel-variabel laten serupa dengan sebuah persamaan regresi linear di antara variabel-variabel laten tersebut. Beberapa persamaan regresi linear membentuk sebuah persamaan simultan varabel-variabel laten. Model persamaan struktural dianalisis dengan bantuan program LISREL 8.51 for Windows.

Hasil analisis model persamaan struktural yang menunjukkan hubungan kausal di antara variabel-variabel penelitian menghasilkan diagram lintasan basic model dengan estimasi standardized solution berikut nilai koefisien pada setiap jalur (Gambar 2). Angka-angka yang ada pada setiap jalur disebut sebagai koefisien struktural, menunjukkan pengaruh langsung (direct effect) antara variabel laten dengan variabel laten lainnya.

Signifikansi hubungan di antara variabel dievaluasi menggunakan nilai koefisien jalur ( $\gamma$ atau $\beta$ ) dan nilai-t (T-Value). Nilai koefisien jalur dan nilai-t dari hubungan-hubungan yang ada sebagaimana dihipotesiskan sebelumnya dirangkum dalam Tabel 3. Hubungan antara variabel eksternal (EXT) dengan persepsi kemudahan menggunakan (PEU) bersifat signifikan. Sementara hubungan antara variabel eksternal dengan persepsi kebermanfaatan (PU) bersifat tidak signifikan. Kebermanfaatan sis- tem informasi akuntansi berbasis komputer di lingkungan LPD tidak ditentukan oleh variabel eksternal yang diidentifikasi dari: (1) latar belakang LPD sebagai lembaga adat dan bersifat tradisional, serta (2) kultur sumber daya manusia pengelola LPD. Penelitian sebelumnya menunjukkan bahwa variabel-variabel eksternal secara konsisten signifikan, namun ada juga beberapa di antaranya yang tidak signifikan [21].

TABEL 3

\begin{tabular}{lccc}
\multicolumn{3}{c}{ RINGKASAN STATISTIK ANALISIS JALUR } \\
\hline & $\begin{array}{c}\text { Koefisien } \\
\text { Jalur }\end{array}$ & Nilai-t & $\begin{array}{c}\text { Signifikansi } \\
(\mathrm{t} \geq 1,96)\end{array}$ \\
\hline EXT $\rightarrow$ PEU & 0.14 & 2.17 & Signifikan \\
EXT $\rightarrow$ PU & -0.11 & -1.58 & Non signifikan \\
PEU $\rightarrow$ PU & 0.16 & 2.42 & Signifikan \\
PEU $\rightarrow$ ATT & 0.09 & 1.77 & Non signifikan \\
PU $\rightarrow$ ATT & 0.55 & 13.45 & Signifikan \\
PU $\rightarrow$ INT & 0.06 & 0.57 & Non signifikan \\
PU $\rightarrow$ ACT & 0.30 & 4.53 & Signifikan \\
ATT $\rightarrow$ INT & 0.12 & -1.34 & Non signifikan \\
INT $\rightarrow$ ACT & 0.01 & -0.22 & Non signifikan \\
\hline Keterangan: & & &
\end{tabular}

Keterangan:

EXT = Variabel Eksternal;

$\mathrm{PEU}=$ Persepsi kemudahan menggunakan;

$\mathrm{PU}=$ Persepsi kebermanfaatan;

AT $=$ Sikap menggunakan;

INT = Minat menggunakan;

$\mathrm{ACT}=$ Penggunaan sesungguhnya

Jalur lain yang bersifat signifikan adalah di antara persepsi kemudahan menggunakan (PEU) dengan persepsi kebermanfaatan (PU), persepsi kebermanfaatan (PU) dengan sikap terhadap menggunakan sistem informasi akuntansi (ATT), serta jalur di antara persepsi kebermanfaatan (PU) dengan penggunaan sistem informasi sesungguhnya (ACT). Sebagian dari temuan penelitian ini sejalan dengan hasil-hasil penelitian sebelumnya, namun sebagian lagi ada yang tidak selaras [22], [23]. Secara keseluruhan faktor eksternal berpengaruh ti- 
dak nyata terhadap penggunaan sesungguhnya sistem informasi akuntansi.

Kecocokan model dievaluasi menggunakan sejumlah kriteria goodness of fit [24]. Tabel 4 menyajikan ringkasan statistik tujuh fit index yang digunakan untuk mengevaluasi kecocokan model. Chi-square $\left(X^{2}\right)$ digunakan untuk menguji seberapa dekat kecocokan antara matrik kovarian sampel dengan matrik kovarian model. Nilai $X^{2}$ yang rendah sehingga menghasilkan significance level lebih besar atau sama dengan $0.05(\mathrm{p} \geq 0.05)$ menunjukkan hipotesis nol diterima dan matrik input yang diprediksi dengan yang sebenarnya tidak berbeda secara statistik. Root Mean Square Error of Approximation (RMSEA) mewakili nilai rerata error dari model. Model dengan nilai RMSEA $\leq 0.05$ menunjukkan kecocokan model yang sangat baik.

TABEL 4

RINGKASAN STATISTIK FIT MODEL

\begin{tabular}{lcc}
\hline \multicolumn{1}{c}{ Fit Index } & Nilai Rekomendasi & Hasil Analisis \\
\hline Chi-square & $\leq 3.00$ & $30.44 / 6=6.74$ \\
/ degrees of & & \\
freedom & & \\
RMSEA & $\leq 0.06$ or $\leq 0.08$ & 0.135 \\
NNFI & $\geq 0.90$ & 0.63 \\
CFI & $\geq 0.90$ & 0.85 \\
RMSR & $\leq 0.10$ & 0.027 \\
GFI & $\geq 0.90$ & 0.96 \\
AGFI & $\geq 0.80$ & 0.85 \\
\hline GFI = goodness-of-fit index $;$ AGFI = adjusted goodness-of- \\
fit index; & \\
NNFI = non-normed fit index $;$ CFI = comparative fit index; \\
RMSR = root mean square residual; \\
RMSEA = root mean square error of approximation.
\end{tabular}

Non-Normed Fit Index (NNFI) merupakan ukuran kecocokan inkremental, yaitu membandingkan model yang diusulkan dengan model dasar (null model). Kisaran nilainya antara 0 sampai 1, dimana nilai NNFI $\geq 0.9$ menunjukkan kecocokan model yang sangat baik. Comparative Fit Index (CFI) juga merupakan ukuran kecocokan inkremental. Nilai $\mathrm{CFI} \geq 0.9$ menunjukkan kecocokan model yang sangat baik. Root Mean Square Residual (RMSR) mewakili nilai rerata residual yang diperoleh dari mencocokkan matrik varian-kovarian dari model yang dihipotesiskan dengan matrik varian-kovarian dari data sampel. Goodness-of-Fit Index (GFI) merupakan ukuran kecocokan absolut, membandingkan model yang dihipotesiskan dengan tidak ada model sama sekali. Adjusted Goodness-of-Fit Index (AGFI) merupakan perluasan dari GFI yang disesuaikan dengan rasio antara degree of freedom dari null model dengan degree of freedom dari model yang dihipotesiskan. Nilai GFI dan AGFI berkisar antara 0 (poor fit) sampai 1 (perfect fit).
Evaluasi terhadap berbagai fit index menunjukkan nilai-nilai RMSR, GFI dan AGFI berada di atas ambang batas yang ditentukan. Berdasarkan ketiga fit index tersebut, dapat dinyatakan terdapat kecocokan antara data empiris dengan model yang diestimasi. Beberapa fit index lainnya mempunyai nilai di bawah ambang batas yang ditentukan. Dalam analisis model struktural memang tidak ada alat uji statistik tunggal untuk mengukur atau menguji hipotesis mengenai model struktural. Umumnya digunakan berbagai jenis fit index (indeks kesesuaian) untuk mengukur derajat kesesuaian antara model yang dihipotesiskan dengan data empirik [24]. Hasil ini memberikan makna bahwa model yang dibangun berdasarkan kajian teoritis belum sepenuhnya didukung oleh data empiris, karena beberapa fit index menghasilkan nilai yang termasuk kategori tingkat kecocokan kurang baik.

\section{Kesimpulan}

Berdasarkan indikator-indikator penggunaan sesungguhnya dari sistem informasi akuntansi di lingkungan LPD ditemukan tingkat penggunaan sistem informasi akuntansi berbasis komputer masih rendah. Hasil penelitian mengindikasikan operasional LPD dalam pemrosesan transaksi, pelaporan keuangan dan pelaporan manajemen belum sepenuhnya memanfaatkan sistem informasi akuntansi berbasis komputer.

Hubungan antara variabel eksternal dengan persepsi kemudahan menggunakan, persepsi kemudahan menggunakan dengan persepsi kebermanfaatan, persepsi kebermanfaatan dengan sikap terhadap menggunakan sistem informasi akuntansi, serta persepsi kebermanfaatan dengan penggunaan sistem informasi sesungguhnya menunjukkan hasil yang signifikan. Sementara jalur lainnya menunjukkan hasil yang tidak signifikan. Pengaruh total faktor eksternal terhadap penggunaan sistem informasi akuntansi menunjukkan hasil yang tidak signifikan. Evaluasi kecocokan model menggunakan beberapa kriteria goodness of fit ditemukan fit index RMSR, GFI dan AGFI berada di atas ambang batas yang ditentukan. Hasil ini memberikan makna bahwa secara keseluruhan model yang dibangun berdasarkan kajian teoritis belum sepenuhnya didukung oleh data empiris.

Direkomendasikan untuk melakukan kajian lanjutan dengan mempertimbangkan indikator-indikator tambahan sebagai bagian dari variabel eksternal agar dapat memberikan gambaran yang lebih komprehensif. Model yang dibangun juga perlu dikaji ulang dengan mempertimbangkan fokus pemanfaatan sistem informasi akuntansi berbasis komputer. 


\section{Referensi}

[1] Grande, E. U., Estébanez, R. P., \& Colomina, C. M. (2011). The Impact of Accounting Information Systems (AIS) on Performance Measures: Empirical Evidence in Spanish SMEs. The International Journal of Digital Accounting Research, 11: 25 - 43.

[2] Ghasemi, M., Shafeiepour, V., Aslani, M., \& Barvayeh, E. (2011). The Impact of Information Technology (IT) on Modern Accounting Systems. Procedia - Social and Behavioral Sciences, 28: 112 - 116.

[3] Petter, S., DeLone, W., \& McLean, E. (2008). Measuring information systems success: models, dimensions, measures, and interrelationships. European Journal of Information Systems, 17: 236-263.

[4] Ilias, A., \& Nazirah, N. (2013). Factor Affecting the Computerised Accounting System (CAS) Usage in Public Sector. Journal of Internet Banking and Commerce, 18(1): 1 19.

[5] Davis, F. D. (1989). Perceived usefulness, perceived ease of use, and user acceptance of information technology. MIS Quarterly, 13(3): 319-340.

[6] Davis, F.D., Bagozzi, R.P., \& Warshaw, P.R. (1989). User acceptance of computer technology: A comparison of two theoretical models. Management Science, 35(8): 9821003.

[7] Adams, D.A., Nelson, R.R., \& Todd, P.A. (1992). Perceived Usefulness, Ease of Use, and Usage of Information Technology: A Replication. MIS Quarterly, 16(2): 227-247.

[8] Davis, F.D. \& Venkatesh, V. (1996). A critical assessment of potential measurement biases in the technology acceptance model: three experiments. International Journal HumanComputer Studies, 45: 19-45.

[9] Venkatesh, V., \& Davis, F.D. (2000). A Theoretical Extension of the Technology Acceptance Model: Four Longitudinal Field Studies. Management Science, 46(2): 186204.

[10] Venkatesh, V., \& Morris, M. G. (2000). "Why Don't Men Ever Stop to Ask For Directions? Gender, Social Influence, and Their Role in Technology Acceptance and Usage Behavior," MIS Quarterly, 24(1): 115-139.

[11] Adamson, I., \& Shine, J. (2003). Extending the new technology acceptance model to measure the end user information systems satisfaction in a mandatory environment: a bank's treasury. Technology Analysis and Strategic Management, 15(4): 441-455.
[12] Barnett, T., Kellermanns, F., Pearson, A., \& Pearson, R. (2006/2007). Measuring information system usage: Replication and extensions. The Journal of Computer Information Systems, 47(2): 76-85.

[13]Fagan, M., Neill, S., \& Woolridge, B. (2008). Exploring the intention to use computers: An empirical investigation of the role of intrinsic motivation, extrinsic motivation and perceived ease of use. Journal of Computer Information Systems, 48(3): 31-37.

[14] Jones, C. M., McCarthy, R. V., Halawi, L., \& Mujtaba, B. (2010). Utilizing the Technology Acceptance Model to Assess the Employee Adoption of Information Systems Security Measures. Issues in Information Systems, $\mathrm{XI}(1): 9-16$.

[15] Agarwal, R., \& Prasad, J. (1999). Are Individual Differences Germane to the Acceptance of New Information technologies?. Decision Sciences, 30(2): 361 391.

[16] Gefen, D., \& Straub, D.W. (1997). Gender Difference in the Perception and Use of Email: An Extention to the Technology Acceptance Model. MIS Quarterly, 12(4): 389 - 400.

[17] Igbaria, M., Zinatelli, N., Cragg, P., \& Cavaye, A.L.M. 1997. Personal Computing Acceptance Factors in Small Firms: A Structural Equation Modelling. MIS Quarterly, 21(3): 279-305.

[18] Karahanna, E., \& Limayem, M. (2000). E-mail and V-mail usage: Generalizing Across Technologies. Journal of Organizational Computing and Electronic Commerce, 10(1): $49-66$.

[19] Moon, J., \& Kim, Y. (2001). Extending the TAM for a World Wide Web Context. Information and Management, 38(4): 217 230.

[20]Lee, Y., Kozar, K.A., \& Larsen, K.R.T. (2003). The Technology Acceptance Model: Past, Future, Present. Communications of the Association for Information Systems, 12: 752780.

[21] Legris, P., Ingham, J., \& Collerette, P. (2002). "Why do People Use Information Technology? A Critical Review of the Technology Acceptance Model". Information \& Management, 40: 191 - 204.

[22] Venkatesh, V., Morris, M.G., Davis, G.B., \& Davis, F.D. (2003). User Acceptance of Information Technology: Toward a Unified View. MIS Quarterly, 27(3): 425-478.

[23] Sriwidharmanely \& Syafrudin, V. (2012). An Empirical Study of Accounting Software Acceptance among Bengkulu City Students. 
52 Journal of Information Systems, Volume 10, Issue 1, April 2014

Asian Journal of Accounting and Governance, 3: 99-112

[24] Hair, Jr., J.F., Black, W.C., Babin, B.J., Anderson, R.E., \& Tatham, R.L. (2006).
Multivariate data analysis. $6^{\text {th }}$ edtion. New Jersey: Pearson Education, Inc. 